\title{
Changes in the Constitutional Review of Legislation in Hungary
}

\author{
István STUMPF CsC \\ Csaba ERDŐS PhD
}

\begin{abstract}
The article presents the changes that had taken place in the relationship between the Parliament and the Constitutional Court through focusing on the development of the Constitutional Court's competences, with particular attention to the review of constitutional amendments and constitutional control over the Parliament's rules of procedure. We place special emphasis on summarizing those voices that had, from the very beginning, harshly criticized the fundamental rights activism of the Constitutional Court and laid the foundations for the political constitutionalism that has pervaded public life since the 2010 elections, as well as the 'public law revolution' grounded in parliamentary sovereignty. This article further discusses new constitutional challenges, such as the joint responsibility of the Parliament and the Constitutional Court in safeguarding national sovereignty and constitutional identity, which opens a new dimension in the separation of powers.
\end{abstract}

\section{Keywords}

constitutional court, parliamentary law, unconstitutional amendment of constitution, national identity, constitutional identity

\section{Introduction}

One of the very first 'products' of the third wave of major social transformations, namely, the change of political system in Eastern Europe which resulted in the establishment of constitutional courts, was the Hungarian Constitutional Court, whose relationship with the National Assembly ${ }^{1}$ has undergone significant changes during the more than three decades of its operation.

This article presents the changes that had taken place in the relationship between the Parliament and the Constitutional Court through focusing on the development of the Constitutional Court's competences, with particular attention to the review of constitutional amendments and constitutional control over the Parliament's rules of procedure. We place special emphasis on summarizing those voices that had, from the very beginning, harshly criticized the fundamental rights activism of the Constitutional Court and laid the foundations for the political constitutionalism that has pervaded public life since the 2010

1 The National Assembly is the Hungarian Parliament; this paper uses these terms interchangeably. 
elections, as well as the 'public law revolution' grounded in parliamentary sovereignty. This article further discusses new constitutional challenges, such as the joint responsibility of the Parliament and the Constitutional Court in safeguarding national sovereignty and constitutional identity, which opens a new dimension in the separation of powers.

\section{The activist Constitutional Court}

One of the very first institutions of the new democracy following the change of political system in Hungary was the Constitutional Court, which started its operation before the first free elections, on 1 January 1990. ${ }^{2}$ Perhaps the most striking feature of the Hungarian political transformation was that the regime change took place through negotiations and compromise, ensuring that the governance and operability of the state was upheld. ${ }^{3}$ With the addition of five new members following the first free elections, the Constitutional Court did not simply join the political process as a new institution responsible for the protection of the constitution, but relying on its autonomy to design its own competences, the Court became a major political player of the regime change. The grave economic heritage of the past system, the party political differences, the tensions straining the coalition government, the new political elite's unpreparedness and lack of experience, and finally, mutual distrust rapidly eroded confidence in the multi-party system. It was in this political vacuum and pervasive distrust that the Constitutional Court became a key player, consciously taking on the role of the rule of law revolutionary, with its activism, its aristocratic detachment, speaking the dogmatic language of legalese.

Through intense doctrinal work in the early nineties, the Constitutional Court laid down the legal foundations of the rule of law with decisions on the statute of limitations, lustration cases, and motions to remedy past injustices. Making up for the lack of a chapter on legislation in the Constitution, the Court subsequently elaborated detailed requirements to guide legislation. Besides the elaborating principles regarding clarity of norms, reasonable time to prepare and public law invalidity, the Constitutional Court also made pronouncements on the democratic legitimacy of the exercise of public authority, the protection of acquired rights, laws requiring qualified majority and the rule of law requirements governing individual areas of law (criminal justice, administrative law and private law). Owing primarily to its normative content, the rule of law played a dominant role in the jurisprudence of the Constitutional Court. It was of particular significance during the period of the 'rule of law revolution' that anyone could directly apply to the Constitutional Court (actio popularis) and the Court could directly review the contested legislative act based on rule of requirements. The Constitutional Court was without doubt Hungary's flagship of legal constitutionalism.

2 The National Assembly of the single-party state adopted Act No. XXXII of 1989 on the Constitutional Court and elected the first five members of the court on 23 November 1989: Antal Ádám, Géza Kilényi, Pál Solt, László Sólyom, János Zlinszky.

3 Several books discuss the change of political regime. One of the most structured accounts of the events is given by Mihály Bihari in: A magyar politika 1944-2004. Politikai és hatalmi viszonyok [Hungarian politics 19442004. Political and power relations], Budapest 2005, 333-413. An account less focused on structural processes ig given by László Kéri in: A rendszerváltás krónikája, 1998-2009 [The chronicles of the regime change, 1998-2009], Budapest 2010. A public law approach is presented by Péter Smuk in: Magyar közjog és politika 1989-2011 [Hungarian public law and politics 1989-2011], Budapest 2011. 
Through its decisions, the Court introduced and entrenched the ideal and the practice of the rule of law, linking it to common European constitutional traditions. ${ }^{4}$

In the Constitutional Court's self-understanding during the period of the change of political system, given the circumstances of that time, activism was, to some extent, unavoidable. The National Assembly as the constitution-maker was not in the position to remedy the discrepancies or fill in the gaps of the existing Constitution, therefore, it was up to the Constitutional Court as the single institution capable of solving those problems through the creative interpretation of the law, that, for lack of political consensus, were otherwise left unresolved. Born amidst the turmoil of the change of political system and intended to be merely a transitional document, the Constitution was initially considered by several members of the Court to be an unfinished text that can only be further improved by a group of esteemed legal professors. It is no wonder, then, that the founding president of the Court later said in an interview: "Our constitutional jurisprudence, particularly when it comes to the 'hard cases' was hovering on the verge of constitution-making, and I had never denied this." 5

The Court understood its own role, born out of intense internal debates, to act as a genuine counterweight to the majority rule. It considered the Constitution, the making of which was in the hands of the Parliament, to be the absolute standard of review. Right until 2011 the majority in the Constitutional Court insisted that it must refrain from a substantive review of constitutional amendments, even though, so the meek counter-argument claimed, "in theory, this could be justified". It was not the interpretation of unconstitutional amendments made to the Constitution that kept the Horn government, holding a two-thirds majority in Parliament, up at night, but much rather dealing with the constitutional veto of the Bokros package $^{6}$ and the attempts at drafting a new constitution. Already then, there were intense debates on whether public law relations should be governed by parliamentary supremacy based on the principle of popular representation, or the protection of fundamental rights through constitutional review. It was these debates that escalated during the second term of the Orbán government, which for its part, held a constitution-making majority.

\section{The victory of the principle of parliamentary sovereignty}

In the background of the debates following the 2010 elections and surrounding the efforts of the parliamentary majority holding a constitution-making majority to transform public law relations is the implicit question whether now, two decades after the change of political regime, the time has come to curb the competences of the overly powerful Constitutional

4 The Venice Commission of the Council of Europe defined the substantive elements of the rule of law the following way: 1. legality and transparent, accountable and democratic legislation, 2. ensuring legal certainty, 3. prohibition of abuse of powers, 4. access to independent and impartial justice, 5. respect for human rights, 6. prohibition of discrimination and the principle of equality before the law. In: CDL-AD (2011) 003rev Report on rule of law - Adopted by Venice Commission at its 86th plenary session (Venice, 25-26 March 2011).

5 A "nehéz eseteknél" a bíró erkölcsi felfogása jut szerephez. Sólyom Lászlóval, az Alkotmánybíróság elnökével Tóth Gábor Attila beszélget [It is the moral stance of the judge that comes to the fore in 'hard cases', Gábor Attila Tóth speaks with László Sólyom, President of the Constitutional Court], in: Fundamentum, 1997, 1; in: HALMAI op. cit., 18, 395.

6 'Bokros package' refers to a set of austerity measures introduced in 1995. The Constitutional Court annulled several elements of the package whose designation hails from the Financial Minister who had elaborated them. 
Court. Analysts close to the national-conservative side kept emphasizing that "what was carried out on behalf of the rule of law by limiting multi-party parliamentarism, is considered today more or less as a repression of democracy. ${ }^{\prime 7}$ They believed that serious distortions had taken place within the constitutional system, drastically limiting the governments' scope of action. Therefore, the excessive separation of powers must be cut back, to restore the supremacy of the elected parliament, and to build a strong government with an efficient public administration. Several proposals were formulated to change the constitutional system and to introduce innovations to the new constitution. ${ }^{8}$ The attacks on the Hungarian government from various European sources were motivated by the ambition of the Hungarian prime minister to repoliticize certain issues and to enforce the mandate given to him by the constituency. This went against mainstream EU politics characterized by the juridification of political issues, i.e. solving problems through legal/judicial avenues. "European politics is characterized by the extreme dominance of human rights logic and the downright limitation of the majority principle which stands in sharp contrast with the principle of the total sovereignty of a one-party parliamentary majority". 9 This line of thinking is the main pillar of political constitutionalism. ${ }^{10}$

Thus, the 'voting booth revolution' also meant the victory of political constitutionalism. The activism of the Constitutional Court was replaced by an activism built on parliamentary supremacy, fueled by a two-thirds majority (super majority). In the course of the election year, the constitutional majority amended the Constitution nine times, while also preparing the Fundamental Law, thereby radically transforming the structure of the Hungarian state system. ${ }^{11}$ These amendments served power political and symbolic purposes, creating

7 According Béla Pokol "In spite of the fact that the parliamentary majority swept away the earlier government with the mandate to bring about change, it is shackled by the detailed provisions of an approximately twentythousand-page collection of the decisions of the Constitutional Court, which, moreover, can be interpreted in many different ways, so that a government majority can never be sure that it will be able to enforce its will." POKOL, Béla: Demokrácia, hatalommegosztás és az állam cselekvőképessége [Democracy, separation of powers and the state's capacity to act], in: Húsz éve szabadon Közép-Európában. Demokrácia, politika, jog [Twenty years of freedom in Central Europe. Democracy, politics, law], SIMON, János (ed.), Budapest 2011, 451.

8 In his aforementioned study, Béla Pokol proposes a more precise normative content of constitutional fundamental rights and obligations, a significant transformation of the powers and functioning of the Constitutional Court, a rethinking of the judicial hierarchy and judicial appointment system, and guarantees of interpretation for the new constitution, which would curb the application of the 'invisible constitution'. POKOL op. cit., 32, 453-455.

9 PÓCZA, Kálmán: Alkotmányozás Magyarországon és az Egyesült Királyságban [Constitution-making in Hungary and the United Kingdom], in: Kommentár, 2012, 5.

10 For critical approach of political constitutionalism see: SAJÓ, András - UITZ, Renáta: The Constitution of Freedom. An Introduction to Legal Constitutionalism, Oxford 2017.

11 The essential elements of the amendments were the following: the first amendment radically reduced the number of members of parliament, introduced the institution of a deputy prime minister, and created the status of government official. The second made it possible to elect someone without municipal representative status to the position of deputy mayor. The third changed the composition of the body appointing constitutional court justices. The fourth reshaped the system of public service media. The fifth vested court clerks with decisionmaking power. The sixth created the conditions for the retroactive taxation of severance payments that brewed a dark political storm. The seventh was to implement the changes made necessary by the repeal of the Act on Legislation, recasting among others the Prosecution Act. The seventh incorporated the supervision of the Hungarian Financial Supervisory Authority and the institution of government commissioner into the constitution. The eighth amendment limited the powers of the Constitutional Court in reviewing acts related to the economy. The ninth amendment incorporated the institution of the National Media and Infocommunications Authority into the text of the Constitution, the president of which is appointed by the prime minister for nine years. Six of the nine constitutional amendments were made at the request of individual representatives! 
a radical shift in the power-sharing system and delegitimizing the 1989 Constitution.

In this new system of division of powers, the sharpest conflicts emerged between the Constitutional Court and the government, closely aligned with the legislature posing in the guise of the constitution-maker. The authors of the Fundamental Law set out to create a Constitution "as solid as granite". The democratic and professional deficiencies of 'revolutionary legislation', the Constitutional Court's 'unbridled lawyering' and the 'intrigues of globalist circles' hiding behind the Venice Commission forced the constitutionmaking majority to adapt the text of the new Fundamental Law successively, through gradual amendments to meet political challenges. Following the fourth amendment to the constitution, the political agenda was no longer dominated by constitutional conflicts.

\section{Power-shift between the National Assembly and the Constitutional Court following the adoption of the Fundamental Law}

\section{Court packing?}

In contrast with the previous constitution, the Fundamental Law declares the principle of the separation of powers: "The functioning of the Hungarian State shall be based on the principle of the separation of powers" [Article C) paragraph (1)]. The new regulation, as opposed to earlier assumptions and the concept prepared by the ad hoc committee, not only preserved the political system of republic, but also refrained from introducing drastic changes to the form of government.

The most significant changes were made to the role of the Constitutional Court in the new power-sharing system. The 2010 amendments to the Fundamental Law saw the government furnish itself with a dominant role in selecting the judges of the Constitutional Court; meanwhile, it limited the powers of the Court in reviewing cases concerning economic constitutionality, finally, it placed the election of the president of the Constitutional Court into the hands of the Parliament and increased the number of justices to 15.

These amendments did not prevent the Constitutional Court from rendering decisions in accordance with the rule of law even in politically sensitive cases. In December 2011, the Court annulled certain provisions of the Media Act. ${ }^{12}$ The following year, the Constitutional Court elaborated the conditions under which it could rely on arguments it had set forth in earlier judgments rendered before the entry into force of the Fundamental Law; ${ }^{13}$ it deemed the 'retirement' of judges at the age of 62 to be unconstitutional; ${ }^{14}$ it annulled the rules criminalizing homelessness ${ }^{15}$ and finally, it considered the concept of family employed in the revised Family Protection Act to be too narrow. ${ }^{16}$ The Constitutional Court's decisions clearly demonstrate that the institution is functioning according to the rule of law, and the Court, with a majority of justices considered to be aligned with Fidesz, is capable of exercising constitutional control over the legislature and the government.

12 With this decision, the Constitutional Court excluded print and online media from under the scope of the Media Act, abolished the institution of 'media ombudsman', found the rules governing the protection of journalist's resources to be unconstitutional and partially limited the investigative powers of $\mathrm{NMHH}$.

13 Decision No. 22/2012. (V. 11.) AB.

14 Decision No. 33/2012. (VII. 4.) AB.

15 Decision No. 38/2012. (XI. 14.) AB.

16 Decision No. 43/2012. (XII. 20.) AB. 


\section{The problem of unconstitutional amendments of the constitution}

Tensions between the Parliament and the Constitutional Court escalated on the turn of 2012 and 2013, when the Court partially annulled the transitional provisions of the Fundamental Law, ${ }^{17}$ and subsequently, upon the ex ante constitutional review request made by the President of the Republic, declared several provisions of the Act on Election Procedure to be unconstitutional. ${ }^{18}$ The two decisions were interconnected, since the second amendment made to the Fundamental Law placed the rules governing registration in the electoral roll (pre-registration) among the transitional provisions of the constitution, accordingly, partial annulment opened up the possibility to review the constitutionality of registration. ${ }^{19}$ During the debate surrounding the decision on the transitional provisions of the Fundamental Law, the Court was faced with serious questions, such as whether it even has the competence to review the Fundamental Law and its amendments, and which category of legal sources transitional provisions belong to. It is the consistent case law of the Constitutional Court that it shall not review the text of the constitution, however, this shall not exclude review in cases where the validity of the amendment is in question.

The Constitutional Court based the possibility of reviewing the transitional provisions on the consideration that with the adoption of the Fundamental Law, the constitution-making power wished to create a stable, durable and consistent legal document, determining its subjects, substance and structure. The Court took the position that based on criteria flowing from the Fundamental Law, only one legal act may be at the apex of the hierarchy of legal sources. This system is broken by the transitional provisions, since they attempt to raise several provisions of permanent nature to the level of the highest legal source, without incorporating them into the body of the Fundamental Law. It may give rise to constitutional uncertainty if the substance or scope of the effective Fundamental Law may be established in several ways. "The Constitutional Court has a constitutional duty to review all laws that compromise the internal unity of the legal system, particularly those that violate the unity of the Fundamental Law itself. As such, it is not only the right, but the constitutional duty of the Constitutional Court to protect the Fundamental Law against all such decisions of the legislature, even when these are underpinned by a two-thirds majority in Parliament, that would impede or jeopardize the enforcement of the provisions of the Fundamental Law, rendering the legal substance, scope and position of the Fundamental Law in the hierarchy of legal sources uncertain, relativizing the substance of the standard of constitutionality, namely, the Fundamental Law. The Constitutional Court's mandate in protecting the Fundamental Law includes the duty to protect the Fundamental Law as a single and unitary document." 20

The Constitutional Court made it clear that without incorporation, no provision can become a part of the Fundamental Law. This 'incorporation rule' also means that amendments cannot

\footnotetext{
17 Decision No. 45/2012. (XII. 29.) AB.
}

18 Decision No. 1/2013. (I. 7.) AB.

19 The Constitutional Court has 30 days to decide ex ante constitutional review petitions. Owing to the Christmas and New Year's Eve festivities this deadline was reduced by half and the preliminary question of the constitutional consideration of transitional provisions also had to be decided. Politicians aligned with the government fabricated conspiracy theories: "One has to assume extreme malice to think the Constitutional Court annulled the transitional provisions to destroy the constitutional basis for electoral registration." (Interview with László Kövér, Válasz).

20 Decision No. 45/2012. (XII.29.) AB. 
cause an unresolvable conflict between the provisions of the Fundamental Law. The Court's decision declared that "the Constitutional Court may even assess whether the enforcement of the substantive constitutional requirements, guarantees and values of the democratic state under the rule of remains unimpeded, and enshrined in the constitution." ${ }^{21}$ The majority reasoning left open the possibility of also a substantive review of constitutional amendments. These two decisions were meant to restore the balance in the power sharing system, between the powers representing political and legal constitutionality. However, the constitution-making majority took the view that the Constitutional Court had herewith crossed the Rubicon and violated the basic political interests of the parliamentary majority, which in turn, enjoys the support of the electorate. While backing down on the issue of voter registration, the constitution-maker decided to take on the Court on the issue of reviewing constitutional amendments.

Not only did the fourth amendment incorporate into the Fundamental Law the majority of the provisions previously annulled on formal grounds, but it also included several provisions which the Constitutional Court had already found to be unconstitutional on substantive grounds. More than ever before, the amendment rearranged the balance of power between the different branches, restricting the Court's room for manoeuvre considerably. In a way, this indirectly barred the Constitutional Court from substantively reviewing the Constitution, meanwhile, in cases of procedural violations, it explicitly allowed for the constitutional review of amendments. The fourth amendment stipulated that the Court was bound by the petition submitted to it, stating that the Court may extend the scope of its review only where there is a close connection with the petition. It further annulled earlier decisions of the Constitutional Court, without excluding the possibility that the court arrive at the same conclusion in its new decisions. Finally, it set a tight deadline for constitutional reviews carried out upon judicial initiative and provided for the partial publicity of the Court's proceedings.

The fourth amendment of the Fundamental Law constitutionalized a concept of the rule of law according to which in a democratic state the only constitution-maker is the National Assembly elected by the people, the parliament exercises this right in formalized procedures by way of representatives who received their mandate through elections, and no restriction of this constitution-making right is recognized. The Constitutional Court may review the constitutionality of the constitutional amendment, but only from a procedural point of view. This means that if the chief depositary of popular sovereignty, the parliament holding the constitution-making majority takes the view that the Constitutional Court rendered a 'flawed' decision, it may make use of its power of constitutional amendment to 'override' the Court's decision by incorporating the unconstitutional rule into the Fundamental Law. Proponents of political constitutionalism believe that democratically elected legislators are better suited and have greater legitimacy to solve problems arising from 'reasonable disagreements'. Meanwhile, judges may enforce minority views without widespread support in the political community, disregarding the majority opinion in an anti-democratic way. In their eyes, the essence of the constitution is not the sum of constraints imposed on political decision-makers through the list of human rights, but much rather democratic decisionmaking, which reserves the final decision for elected politicians. As far as the separation of

21 The decision was adopted with concurring opinions from Justices András Holló and István Stumpf as well as dissenting opinions from Justices István Balsai, Egon Dienes-Oehm, Barnabás Lenkovics, Péter Szalay and Mária Szívós. 
power is concerned, checks and balances are not guaranteed through institutional vetopowers (such as e.g. the Constitutional Court), but the competition between parties in free elections and the possibility of changing parliamentary majorities. ${ }^{22}$

Until the constitution is adopted, constitution-making power is indeed unlimited, however, in practice it must comply with international ius cogens, the formal procedural rules governing constitution-making, as well as the principle of the integrity of the constitution (no rule may be incorporated into the constitution which is in an irreconcilable conflict with other constitutional provisions). Since the Fundamental Law does not distinguish between constitution-making and constitution amending powers, the current government, supported by a two-thirds majority in parliament, is of the view that there are no restrictions on acts amending the constitution.

In a democratic state governed by the rule of law there can be no unlimited power, as such, the constitution-making power cannot be unlimited either, since besides the constraints mentioned above, the latter is bound by the effective constitution, the Fundamental Law's system of norms. The Fundamental Law established the constitutional system of the separation of powers where the Constitutional Court as the chief guardian of the Fundamental Law has the constitutional obligation to take action against any restriction or hollowing out of the norm placed at the apex of the hierarchy of laws. It is up to the Constitutional Court to exercise its functions of protecting the constitution to the extent this is allowed under the Fundamental Law and the rules governing its interpretation. Of course, any revision of constitutional amendments cannot result in the usurpation of constitution-making powers. That is, the Constitutional Court must always respect the provisions of the Fundamental Law, it must always render its decisions on the basis of the Fundamental Law. It is the responsibility of the National Assembly to respect the Fundamental Law it had adopted, in order to maintain the level of constitutionality hitherto achieved. The Constitutional Court established the rule of incorporation, namely, that amendments and supplements to the Fundamental Law must be incorporated into the structure of the Fundamental Law in a coherent way. Accordingly, amendments to the Fundamental Law may not give rise to an irreconcilable conflict within the constitution. The rule of law guaranteed under Article B) paragraph (1) of the Fundamental Law requires both the substantive and structural coherence of constitution, which must be ensured by the constitution-making power. ${ }^{23}$

"The uniform, non-contradictory character of the constitution is not a self-serving conceptual construct. An effective condition for constitutional adjudication, and thus, for the legitimacy of the constitution protected is that the legal norm at the apex of the legal system be suitable to serve as the foundation for the consistent legal practice of the Constitutional Court. It should be noted that from this perspective, preserving the

22 In a recent paper, Béla Pokol supplements political constitutionalists' arguments with the international perspective "[the] decisions of the Strasbourg ECtHR and the global consitution - would submit the constitution, constitutional amendments and the consitution-making power under their control based on presciptions of advisory bodies and constitutionalized 'general' international law. This would close the circle and the most important attribute of the sovereign state, namely, disposal over the constitution-making power, would cease to exist within the state." In the conclusion to his paper, Pokol envisions the threat of a global constitutional oligarchy taking shape. POKOL, Béla: Az alkotmánybíráskodás szociológiai és politológiai kérdései [Sociological and politological questions of judicial review], in: Jogelméleti Szemle, 2013, 4.

23 Stumpf summarizes the jurisprudence of the Constitutional Court and the views on the unity of the constitution in detail in the concurring opinion attached to Decision No. 45/2012. (XII.29.) AB and the minority opinion written on the fourth amendment to the Fundamental Law. 
unity of the constitution also lies in the interest of the legislator as well as the social order established under the constitution. (...) The cornerstone of the legal system cannot be unstable or unpredictable due its uncertain content. (...) In every country, it is up to the constitutional court to guarantee the coherence of the constitution."24

There is no democratic alternative to the rule of law, moreover, effective governance cannot be successfully achieved without a stable constitutional foundation. Just as the historical constitution could not be purged from Hungarian public law culture, so the over twenty years of legal development pursued by the Constitutional Court cannot be airbrushed from Hungarian constitutional culture either. Nor could the political elite of the regime change try and push the responsibility for their own inability to make their own decisions and foster agreements to the Constitutional Court, which in turn, was showing excessive activism. We are now dealing with the exact opposite situation, with the government taking a number of decisions with far-reaching socio-economic consequences. The government will have to shoulder the responsibility for these decisions and the electorate will decide whether they agree with these measures. The Constitutional Court is not competent to judge political decisions, but it has the power to review the constitutionality of matters before it, indeed, this is the Court's constitutional duty. The constitution-making majority removing budgetary and tax issues from under constitutional control for short-term interests will seriously damage the rule of law and economic constitutionality. By regularly annulling decisions of the Constitutional Court it does not agree with through "constitutionally over writing them" the government undermines the unity and the non-contradictoriness of the constitution, inviting the accusation of abusive constitutionalism. ${ }^{25}$ In the system of the separation of powers, it is not only the constitutional principle of the separation of powers that must prevail, but also the requirement for co-operation. Where the parliamentary majority has constitution-making power, the Constitutional Court bears great responsibility since it is the only institution that can act as a real counterweight. It is in a consolidated period that it becomes clear to what extent the national parliament and government rely on the institution policing the constitution, namely, the Constitutional Court. It is in the common interest of constitutional institutions, indeed, I would say it is in the national interest, that the underlying values and provisions of the Fundamental Law win the sympathy of the citizens, which they are willing to follow. If we sacrifice values such as the rule of law and constitutional stability for short-term power interests, our entire society will pay the price. In a democratic state governed by the rule of law, the division of power should not be in the service of defeating the other, but in a system of constitutional responsibility built on mutual support and limitation for the fullest possible service of the public good.

24 CSINK, Lóránt - FRÖHLICH, Johanna: A régiek óvatossága. Megjegyzések az Alaptörvény negyedik módosításának javaslata kapcsán [The cautiousness of our forefathers. Comments apropos the draft on the fourth amendment to the Fundamental Law]. In: Pázmány Law Working Papers, 2013, 1, 5-6.

25 In his recent work, US professor of law, David Landau cites Hungary besides Venezuela and Columbia as an example for abusive constitutionalism LANDAU, David: Abusive constitutionalism, in: University of California, Davis Law Review, 47, 2013, 1, 189-260, online: lawreview.law.ucdavis.edu/issues/47/1/Articles/47-1_Landau. pdf. 


\section{Normative and individual acts of Parliament before the Constitutional Court}

\section{Overview}

In addition to reviewing constitutional amendments, another important watershed in the relationship between parliaments and constitutional courts is the constitutional review of internal parliamentary legal procedures, that is, parliamentary rules of procedure adjudication in the broadest sense. In what follows, we will only focus on the self-regulatory (self-administrative) acts of the Parliament, namely, provisions of the house rules as well as customary law rules giving flesh to the house rules.

\section{Normative foundations}

Of the many powers of the Constitutional Court the most important ones are the ex-ante and ex-post constitutional review, as well as the constitutional complaint aimed at reviewing acts of Parliament.

The three most important normative sources of parliamentary law can be the subject of ex-ante and ex-post constitutional review: the Fundamental Law, the Act on the National Assembly (hereinafter: the ANA) and the provisions of the Rules of Procedure (hereinafter: RoP). Since the fourth amendment of the Fundamental Law, the Constitutional Court may not review the substance of the Fundamental Law and its amendments, but only their adoption based on the constitutional rules on enactment and promulgation, which constitutes a meaningful limitation to the Court's constitutional review powers over norms concerning the Parliament.

The ex ante constitutional review of laws, such as the ANA may be petitioned by the Parliament by a simple majority or by the President. As a general rule, Hungarian law does not know the ex ante constitutional review of normative decisions, therefore, the ex ante review of the RoP is provided for under a separate provision of the Act on the Constitutional Court. However, the statutory scope of petitioners hardly corresponds to the widely accepted constitutional purpose of the review of house rules, namely, the protection of the political minority. This is because the ex ante constitutional review related to the RoP may be petitioned by the person who had submitted the draft resolution, the government or the Parliament itself, upon the proposal of the Speaker of the Parliament. The opposition has a meager chance of initiating a successful resolution, the Government will most probably enforce its will in the parliamentary vote on the draft resolution, as such, it is not in its interest to turn to the Constitutional Court directly or through Parliament.

The scope of those entitled to petition ex post abstract constitutional review is not tailored to the interests of the opposition, either. Prior to the entry into force of the Fundamental Law, access to the Constitutional Court through actio popularis was greatly reduced. Of the possible petitioners specified in the Fundamental Law, only the Ombudsman and a fourth of the Members of Parliament have so far exercised this right. Thus, the politically divided opposition must either come together or rely on the support of an external power, the Ombudsman. In fact, there have been examples of such alliances among the opposition as well as successful ex-post constitutional review petitions, even in a matter with parliamentary law relevance. 
Not only did the entry into force of the Fundamental Law repeal the general right to petition the Constitutional Court for ex post constitutional review, but it also introduced the direct and genuine constitutional complaint that was hitherto unknown to the Hungarian legal system. As acts of Parliament cannot be challenged before ordinary courts, of the types of constitutional complaints, only the direct constitutional complaint has real relevance, since genuine constitutional complaints are only admissible, if they contest judicial decisions. Direct constitutional complaints are particularly relevant in the context of parliamentary autonomy, since they may also be geared towards challenging sui generis sources of parliamentary law. Indeed, acts of Parliament also include a number of specific executive acts, such as decisions on the conduct of sittings, parliamentary policing and disciplinary decisions, or decisions regarding the mandate of dignitaries, which give flesh to the relevant normative constitutional provisions and house rules. There are also special sources of parliamentary law, which do not take the form of constitutional, legislative or normative decisions, but which are nevertheless of a normative nature, forming the basis for issuing individual acts. These sources include presidential decrees or house committee resolutions. These are the sources of parliamentary law that are difficult to classify from a theory of legal sources point of view, but there is no doubt that owing to their role in detailing and interpreting house rules they are essential for the functioning of the parliament as well as for the exercise of parliamentary duties and powers. Since these decisions do not qualify as either legislation or as public law regulatory instruments, they cannot be the subject of ex post abstract constitutional review, so the only way to challenge their constitutionality is to file a constitutional complaint.

The strict system of conditions for the admissibility of a direct constitutional complaint, in particular, the extremely stringent deadline, reduce the chances of substantively reviewing a petition contesting parliamentary law to a minimum. It should also be emphasized that various acts adopted in Parliament, which are typically individual decisions, cannot be challenged before the Constitutional Court, not even through a direct constitutional complaint. It is merely the norm based on which the act was adopted, that may be challenged, with the exception of the Fundamental Law of course. Consequently, there are a significant number of acts of parliament that cannot be challenged.

The most important decisions of the Constitutional Court rendered on parliamentary law From among the decisions of the Constitutional Court, we shall only focus on the most important decisions concerning parliamentary law, yet even from these few cases it is clear how much the Court's willingness to influence the 'internal affairs' of the Parliament has changed.

Decision No. 50/2003. (XI. 5.) AB was based on several petitions, one of which was a constitutional complaint alleging that the legislator had provided no legal remedy against the report of the parliamentary inquiry committee. This state of affairs seemingly complied with Article 57 paragraph (5) of the Constitution in force at the time, as it only required the provision of legal remedies against judicial, administrative and other decisions rendered by public authorities. However, this provision of the Constitution was given a broad interpretation by the Constitutional Court, who established the violation of the Constitution through omission: "According to the findings of the Constitutional Court, 
the activities of the parliamentary committees conducting the investigation qualify as the exercise of public authority. It follows from Article 57 (5) of the Constitution that an appeal against decisions taken in the course of this activity affecting the rights, obligations and legitimate interests of citizens and other persons must be provided." This means that the Constitutional Court justified the classification of the activity of the inquiry committee as an exercise of public authority by reference to the fact that the committee makes decisions affecting the rights, obligations and legitimate interests of persons. Thus, in this decision, the Constitutional Court conducted a substantive review of parliamentary law relying on a broad interpretation of both its powers and the Constitution.

In Decision No. 9/2008. (I. 31.) AB the Constitutional Court ruled that the decision on the election of the President is of individual character, and owing to this quality, it cannot be reviewed by the Court. Hence, in this case, the Court interpreted its powers narrowly.

Decision No. 10/2013. (IV. 25.) AB was based on a constitutional complaint submitted by ten independent deputies, in which they sought the annulment of an amended RoP provision on the formation of political factions. It was argued, increasing the minimum number of MPs required for forming a new political faction to 12 and stipulating that only members of the party that had promoted an electoral list and won a seat in the previous elections may establish a faction violates the Fundamental Law. The Constitutional Court, however, stressed that "the Parliament enjoys a high degree of organizational leeway, whose limitations lie in the respect for the Fundamental Law. (...) Thus, the National Assembly independently decides all matters concerning its organization and operation which are not regulated by the Fundamental Law or other acts; the only substantive requirement regarding such decisions, i.e. internal organizational rules is that they do not violate the Fundamental Law."

The petitions underlying Decisions No. 3206/2013. (XI. 18.) AB and 3207/2013. (XI. 18.) AB contested decisions on disciplinary fines, in effect challenging several different disciplinary rules enshrined in the ANA. According to the Fundamental Law, "Everyone shall have the right to seek legal remedy against any court, authority or other administrative decision which violates his or her rights or legitimate interests". Thus, a decade after the 2003 decision of the Constitutional Court, and the entry into force of the Fundamental Law notwithstanding, the question remains the same: can a parliamentary act be qualified as a judicial, public authority or other administrative decision? As far as disciplinary decisions were concerned, the Constitutional Court answered without embarking upon an in-depth assessment: the absence of a remedy against such decisions shall not in itself result in a situation that is unconstitutional". This statement is repeated almost verbatim in Decision No. 3207/2013. (XI. 18.) AB. The Constitutional Court dealt with disciplinary and parliamentary policing related decisions in a similar way as it proceeded in respect of the National Assembly's internal organizational freedom: "Article 5 (7) of the Fundamental Law guarantees the right for the National Assembly to lay down its own internal rules and protocol for sittings in the Rules of Procedure adopted by a two-thirds majority of the Members of Parliament present. The National Assembly enjoys great freedom in drafting the provisions of the Rules of Procedure; its self-regulatory autonomy is a competence protected under the Fundamental Law, in which the Constitutional Court may intervene only in extreme cases and on the basis of very serious arguments and reasons, where there is a direct violation of the constitution." 
In summary we may conclude that neither the normative framework, nor the jurisprudence of the Constitutional Court point into the direction of the Court becoming an institution for policing the Parliament's Rules of Procedure, indeed, in exercising its powers in relation to the National Assembly, the Constitutional Court opts for providing the Parliament greater regulatory leeway.

\section{Beyond legal and political constitutionalism: The interdependence of the National Assembly and the Constitutional Court}

\section{A new level in the separation of powers}

The intensity of the constitutional debates surrounding the public law upheaval following the adoption of the Fundamental Law has subsided, giving way to issues related to national sovereignty and constitutional identity. Having joined the European Union following the millennium, Central and Eastern European Member States left their socialist ideological past behind, a system that for a long time sought to standardize their public law structures. These countries are now, at this stage of integration forced to give shape to and accept their own constitutional identity while at the same time, persuade the European Union to recognize new identity as well. "In the early stages of integration, tolerance towards the primacy of EU law was the 'ticket' for Member States to join the club of a united Europe." At present, especially after Brexit, it is the continued operation (and quality) of the club that is at stake, so it is now also up to the European Union to "respect the principle of constitutional tolerance and to 'endure' the constitutional identity of the Member States so that the club can continue to operate smoothly". ${ }^{26}$

Today, the European Union is somewhere between a community of law and an independent state. ${ }^{27}$ It has reached the critical mass that increasingly encourages Member States to mark out their own 'limits of sovereignty'. The legal systems of the European Union and Hungary are interconnected. We are witnessing a gradual widening of this relationship. The socalled 'integrationist' approach promoting such widening "forces Member States from the often misunderstood and poorly contextualised, yet objectively important sovereigntist perspective to redefine their relationship and that of the national constitutional (system) with the European Union". ${ }^{28}$

The European Union is basically built on the primacy of European Union law. In practice, primacy is derived from the principles of interpretation and application of law (e.g. effet utile, supremacy of Community law, direct effect and direct applicability) flowing from primary law and the case law of the Court of Justice of the European Union (CJEU)..$^{29}$ These

26 SULYOK op. cit. 46.

27 French Professor Bertrand Mathieu's book is among the very few books which discusses the key issues democracy and the constitutional state based on rule of law from a 'sovereigntist' viewpoint. "We need a strong, organized and culturally homogenous society on the national level. Meanwhile, a further level may also exist, which is open to the differences between its constituent peoples, which is enriched by the diversity of national culture, and which is united around the common heritage... The goal must therefore be a Europe of the nations and not a Europe substituting the nations." in: MARHIEU, Bertrand: A jog a demokrácia ellen? [Law against democracy?], Budapest 2018, 215.

28 SULYOK, op. cit. 47.

29 Cf. Costa/ENEL case, 15 July 1964, 6/641 [1]; and 22 June 2007 Opinion of the Commission's Legal Service. 
rules and principles have all helped the European Union in positing its own law (and hence its own 'self-limits') in relation to that of the Member States. In this context, the CJEU has also stated that Member States may not invoke their own constitutional arrangements in order to apply EU law selectively or in a discriminatory manner.

However, Community law also has its own self-imposed limits. An important new limit was introduced by the Treaty of Lisbon, the treaty that was actually designed to achieve an integration closer than ever between the Member States. Article 4 (2) of the Treaty on European Union (TEU), as amended by the Treaty of Lisbon, makes it clear that there is a protected core of national sovereignty which a Member State may preserve: "The Union shall respect the equality of Member States before the Treaties as well as their national identities, inherent in their fundamental structures, political and constitutional, inclusive of regional and local self-government. It shall respect their essential State functions, including ensuring the territorial integrity of the State, maintaining law and order and safeguarding national security. In particular, national security remains the sole responsibility of each Member State".

National parliaments and national constitutional courts have a key role to play in both interpreting and protecting national identity. Their cooperation is essential for protecting national sovereignty and constitutional identity. In case of dispute, it is ultimately up to the constitutional courts to give substance to the notion of constitutional identity and, if necessary, to enforce it.

Nevertheless, it is not necessary, or even appropriate, for national constitutional courts to carry out this interpretative activity in complete isolation, only looking inwards, instead, Member States' constitutional courts can carry out their interpretative task most effectively in close cooperation with each other and in dialogue with the CJEU.

\section{In pursuit of constitutional identity}

Hungary has had a written constitution since 1949, nevertheless, the Fundamental Law restored the constitutional continuity that had previously been disrupted. The National Avowal declares that "We honour the achievements of our historical constitution and we honour the Holy Crown, which embodies the constitutional continuity of Hungary's statehood and the unity of the nation." The normative provisions of the Fundamental Law assign a more specific role to our historical constitution. According to Article R (3), "The provisions of the Fundamental Law shall be interpreted in accordance with their purposes, the National Avowal contained therein and the achievements of our historical constitution." Ferenc Deák said "Our constitution is a historical constitution, which was not made at the same time, but rather developed from the experiences of our nation, always in light of the needs of the nation and the necessities of those times [...] changing from time to time both in essence and in form." ${ }^{30}$ Thus, the Hungarian historical constitution is a living reality, evolving organically, at the same time, it is also intended to provide the community with relative stability for generations to come: "our ancestors have endowed

30 DEÁK, Ferenc: Adalék a magyar közjoghoz - Észrevételek Lustkandl Venczel munkájára [More on Hungarian public law - Observations on the work of Venczel Lustkandl]: "Das ungarisch-österreichische Staatsrecht" A magyar közjog történelmének szempontjából ["The Hungarian-Austrian public law" from the perspective of the history of Hungarian public law], Pest 1865, 88. 
us with the Hungarian constitution, a culmination of centuries' worth of achievements, which took shape gradually, forged in the life of the nation, and it is our duty to pass it on to our descendants if possible in the very same form, indeed, we must ensure that its force extends not only to our lives as mortals, but that it be transferred, as a solid legal basis, not unlike bricks and mortar, from generation to generation." 31

According to this quote, Deák perceives the constitution as an identity-shaping document. If we are to consider the constitution as the "identity card of the nation", then in contrast with the neutral text of the previous constitution, one of the most important tasks of the Fundamental Law is precisely to enumerate the achievements of the historical constitution as an interpretative backdrop.

But what should we consider an achievement within our historical constitution? A scholarly approach defines the concept "achievement as a term meaning the result of a struggle, an enduring effort, which is the outcome of an organic development", yet it also stresses, that "something does not necessarily become an achievement of the historical constitution just because it formed part of the historical constitution, otherwise the scope of institutions pertaining to the achievements of the historical constitution would be too wide" ${ }^{32}$ The Constitutional Court did not provide a general definition for the concept, however, in some of its decisions the Court classified certain legal institutions, such as judicial independence, religious freedom and freedom of the press, as achievements of the historic constitution. Based on the provisions of the Fundamental Law [Articles (B) and C)] and the recital of the National Avowal mentioned above referring to the Holy Crown, it can be reasonably argued that the separation of powers, the rule of law and popular sovereignty also fall under the scope of such achievements, since these principles are but the contemporary manifestations of the Holy Crown doctrine. ${ }^{33}$

The first important milestone in the development of our national (constitutional) identity is the Decision No. 22/2016. (XII. 5.) AB of the Constitutional Court, in which the Court interpreted the so-called 'EU clause' of the Fundamental Law. According to the clause enshrined in Article E) paragraph (2) "With a view to participating in the European Union as a Member State and on the basis of an international treaty, Hungary may, to the extent necessary to exercise the rights and fulfil the obligations deriving from the Founding Treaties, exercise some of its competences set out in the Fundamental Law jointly with other Member States, through the institutions of the European Union." The reasoning of the decision clarifies that "the concept of constitutional identity in the Hungarian Constitutional Court understanding means Hungary's constitutional self-identity." The decision further expressly provided that "in exercising its powers, the Constitutional Court may, upon a petition to that effect, examine whether the joint exercise of competences based on Article E) paragraph (2) of the Fundamental Law violates human dignity, other

31 Draft reaction to the royal rescipt submitted by Ferenc Deák on 14 March to the House of Representatives. In: FARKAS, Albert (ed.): Album of the National Assembly, 1866, 1867, Pest 1867, 227.

32 SULYOK, Márton: Nemzeti és alkotmányos identitás a nemzeti alkotmánybíróságok gyakorlatában [National and constitutional identity in the jurisprudence of national constitutional courts], in: Nemzeti identitás és alkotmányos identitás az Európai Unió és a tagállamok viszonylatában [National identity and constitutional identity from the perspective of the European Union and the Member States], Szeged 2014, 33.

33 STUMPF, István: Constitutional Identity and the Scope of the (Administrativ) Implementation of European Decisions, Budapest 2017, 172-173. 
fundamental rights or Hungary's sovereignty or its self-identity stemming from its historical constitution." As far as the substance of constitutional identity is concerned, the reasoning set forth that this "will be elaborated on the basis of the Fundamental Law as a whole, as well as its individual provisions, and, in line with Article R) paragraph (3), these shall be interpreted from case to case according to their purpose, the National Avowal and the achievements of our historical constitution." Thus, in this decision, the Constitutional Court made it clear that firstly, that constitutional identity may constitute a limitation to the exercise of EU competences. Second, the Court also vindicates the right to establish the substance of the Hungarian constitutional identity through interpretation. Thirdly, from the formula outlined above, it is clear that the Court will take consider the historical dimension in its interpretation. With this decision, the Constitutional Court established three bases for review: the test based on the fundamental rights reservation, sovereignty control, and identity control. Those criticizing the decision ${ }^{34}$ accuse the Court of not having gone far enough and only making an attempt to symbolically substitute the failed seventh amendment of the Fundamental Law. The Constitutional Court, however, was not in the position to take over the role of the constitution-making power and, in the absence of an express legal basis, could not expand beyond its powers.

In the 2018 elections, the governing parties (Fidesz-KDNP) gained yet again a constitutionmaking majority in parliament, and thus finallysucceeded in adopting the seventh amendment to the Fundamental Law. ${ }^{35}$ The amendment enshrined the concept of constitutional identity into the text of the constitution, a concept that stems from the historical constitution and which all state bodies are bound to protect. In the second paragraph of Article E), the constitution-making power identified the inalienable elements of national sovereignty, which in turn, constitute the limitations for the exercise of competences by EU institutions. This was the constitutional basis upon which the Constitutional Court rendered its decision on the issue of the Government's interpretation of the constitution. ${ }^{36}$ Developing its earlier decision further, the Constitutional Court stated that the legal basis for the application of EU law in Hungary is the Hungarian constitution. In its interpretation of the Fundamental Law, the Court takes into account the obligations associated with EU membership as well as the obligations undertaken by Hungary in international treaties, maintaining that no institution

34 For a detailed analysis and critique of the decision, see: DRINÓCZI, Tímea: A 22/2016. (XII.5.) AB határozat: mit (nem) tartalmaz és mi következik belöle - Az identitásvizsgálat és az ultra vires közös hatáskörgyakorlás összehasonlító elemzésben [Decision No. 22/2016. (XII. 5.) AB: what it (does not) contain and what follows from it - A comparative analysis of identity control and ultra vires joint exercise of powers], in: MTA Working Law Papers, 2017, 1; and also: HALMAl, Gábor: Abuse of Constitutional Identity. The Hungarian Constitutional Court on Interpretation of Article E) (2) of the Fundamental Law. In: Review of Central and East European Law. In: Review of Central and East European Law, 43, 2018, 1, 23-42.

35 The Fundamental Law of Hungary. National Avowal. "We hold that the protection of our identity rooted in our historic constitution is a fundamental obligation of the State." Article E) para (2) With a view to participating in the European Union as a Member State and on the basis of an international treaty, Hungary may, to the extent necessary to exercise the rights and fulfil the obligations deriving from the Founding Treaties, exercise some of its competences arising from the Fundamental Law jointly with other Member States, through the institutions of the European Union. Exercise of competences under this paragraph shall comply with the fundamental rights and freedoms provided for in the Fundamental Law and shall not limit the inalienable right of Hungary to determine its territorial unity, population, form of government and state structure. Article R) para (4) The protection of the constitutional identity and Christian culture of Hungary shall be an obligation of every organ of the State."

36 Decision No. 2/2019. (III.5.) AB. 
may encroach upon the Constitutional Court's interpretation of the Fundamental Law. Since compliance with EU law is foreseen under the Fundamental Law as a constitutional obligation, possible conflicts should be resolved through constitutional dialogue. This notwithstanding, the authentic interpretation of the Hungarian Fundamental Law is the exclusive task of the Hungarian Constitutional Court, which all other bodies and institutions must respect.

According to the National Avowal "We are proud that our king Saint Stephen built the Hungarian State on solid ground and made our country a part of Christian Europe one thousand years ago." A thousand years ago, King St. Stephen took a decision - the Fundamental Law restores continuity with this resolution. Continuity however, goes beyond the symbolic, since Article E) paragraph (1) also provides that "In order to enhance the liberty, well-being and security of the people of Europe, Hungary shall contribute to the creation of European unity".

European identity also forms part of Hungarian identity. In addition to preserving and protecting this identity for the benefit of our nation, both Parliament and the Constitutional Court must work towards enriching our common European identity with our Hungarian identity.

\section{Summary}

As the paper tried to highlight, the relationship between the Parliament and the Constitutional Court can be interpreted as a way which has several periods within this relation showed newer and newer dimensions and specialties. In each period the Constitutional Court's role was quite solidly determinate by political circumstances. It begun with the bloodless revolution's legacy, which led to a political vacuum within the Constitutional Court became a key player. Although the activism of the Constitutional Court eased after the millennium, it still remained the strongest counter-power of the majoritarian policy making. Its strength became visible again after the 2010 parliamentary election: with their two-third majority governmental parties started to reshape the constitutional system without the need of oppositional support. The Constitutional Court had to face the challenge of anti-constitutional constitution-amendments between 2010 and 2013. During this period the Constitutional Court's competency was also modified - these modifications overwhelmingly point into the direction of restriction - and the Constitutional Court did not try to extend its limited competencies - the political constitutionalism seemed to defeat the legal constitutionalism. Due to the debates on separation of powers between the EU and member states sharpened - highlighted by the migrant and financial crises and also by the Brexit - the two "giants", the Parliament and the Constitutional Court became allies in a new front: both has the constitutional obligation to protect Hungary's constitutional identity, so both Parliament and the Constitutional Court must work towards enriching our common European identity with our Hungarian identity. 


\section{References}

\section{Legal sources}

\section{Basic Law of Hungary}

- Act No. XX of 1949 on the Constitution of the Republic of Hungary

- Act No. XXXII of 1989 on the Constitutional Court

- Act No. CLI of 2011 on the Constitutional Court

- Decision No. 50/2003. (XI. 5.) AB

- Decision No. 9/2008. (I. 31.) $A B$

- Decision No. 22/2012. (V. 11.) AB.

- Decision No. 33/2012. (VII. 4.) AB.

- Decision No. 38/2012. (XI. 14.) AB.

- Decision No. 43/2012. (XII. 20.) AB.

- Decision No. 45/2012. (XII. 29.) AB.

- Decision No. 1/2013. (I. 7.) AB.

- Decision No. 10/2013. (IV. 25.) AB

- Decision No. 3206/2013. (XI. 18.) AB

- Decision No. 3207/2013. (XI. 18.) AB

- Decision No. 2/2019. (III. 5.) AB

CDL-AD (2011) 003rev Report on rule of law - Adopted by Venice Commission at its $86^{\text {th }}$ plenary session (Venice, 25-26 March 2011).

Costa/ENEL case, 15 July 1964, 6/641 [1]; 22 June 2007.

A "nehéz eseteknél" a bíró erkölcsi felfogása jut szerephez. SÓLYOM Lászlóval, az Alkotmánybíróság elnökével TÓTH Gábor Attila beszélget [lt is the moral stance of the judge that comes to the fore in 'hard cases', Gábor Attila TÓTH speaks with László SÓLYOM, President of the Constitutional Court], in: Fundamentum, 1997, 1.

BIHARI, Mihály: A magyar politika 1944-2004. Politikai és hatalmi viszonyok [Hungarian politics 1944-2004. Political and power relations], Budapest 2005.

CSINK, Lóránt - FRÖHLICH, Johanna: A régiek óvatossága. Megjegyzések az Alaptörvény negyedik módosításának javaslata kapcsán [The cautiousness of our forefathers. Comments apropos the draft on the fourth amendment to the Fundamental Law], in: Pázmány Law Working Papers, 2013, 1.

DEÁK, Ferenc: Adalék a magyar közjoghoz - Észrevételek Lustkandl Venczel munkájára [More on Hungarian public law - Observations on the work of Venczel Lustkandl]: "Das ungarisch-österreichische Staatsrecht" A magyar közjog történelmének szempontjából ["The Hungarian-Austrian public law" from the perspective of the history of Hungarian public law], Pest 1865. 
DRINÓCZI, Tímea: A 22/2016. (XII.5.) AB határozat: mit (nem) tartalmaz és mi következik belöle $-A z$ identitásvizsgálat és az ultra vires közös hatáskörgyakorlás összehasonlító elemzésben [Decision No. 22/2016. (XII. 5.) AB: what it (does not) contain and what follows from it - A comparative analysis of identity control and ultra vires joint exercise of powers], in: MTA Working Law Papers, 2017, 1.

FARKAS, Albert (ed.): Album of the National Assembly, 1866, 1867. Pest 1867.

HALMAI, Gábor: Abuse of Constitutional Identity. The Hungarian Constitutional Court on Interpretation of Article E) (2) of the Fundamental Law. In: Review of Central and East European Law, 43, 2018, 1, 23-42.

KÉRI, Lászó: A rendszerváltás krónikája, 1998-2009 [The chronicles of the regime change, 1998-2009], Budapest 2010.

LANDAU, David: Abusive constitutionalism, in: University of California, Davis Law Review, 47, 2013, 1, 189-260, online: lawreview.law.ucdavis.edu/issues/47/1/Articles/47-1_Landau. pdf.

MATHIEU, Bertrand: A jog a demokrácia ellen? [Law against democracy?], Budapest 2018.

POKOL, Béla: Demokrácia, hatalommegosztás és az állam cselekvőképessége [Democracy, separation of powers and the state's capacity to act], in: Húsz éve szabadon KözépEurópában. Demokrácia, politika, jog [Twenty years of freedom in Central Europe. Democracy, politics, law], SIMON, János (ed.), Budapest 2011.

POKOL, Béla: Az alkotmánybíráskodás szociológiai és politológiai kérdései [Sociological and politological questions of judicial review], in: Jogelméleti Szemle, 2013, 4.

PÓCZA, Kálmán: Alkotmányozás Magyarországon és az Egyesült Királyságban. [Constitution-making in Hungary and the United Kingdom], in: Kommentár, 2012, 5.

SAJO', András - UITZ, Renáta: The Constitution of Freedom. An Introduction to Legal Constitutionalism, Oxford 2017.

SMUK, Péter: Magyar közjog és politika 1989-2011 [Hungarian public law and politics 1989-2011], Budapest 2011.

STUMPF, István: Reinventing Government. Constitutional Changes in Hungary, Budapest 2017.

SULYOK, Márton: Nemzeti és alkotmányos identitás a nemzeti alkotmánybíróságok gyakorlatában [National and constitutional identity in the jurisprudence of national constitutional courts], in: Nemzeti identitás és alkotmányos identitás az Európai Unió és a tagállamok viszonylatában [National identity and constitutional identity from the perspective of the European Union and the Member States], Szeged 2014. 


\section{Author}

\section{István STUMPF CsC}

Széchenyi István Egyetem, Deák Ferenc Állam- és Jogtudományi Kar

Széchenyi István University, Faculty of Law and Political Sciences

Egyetem tér 1., 9026 Győr, Hungary

University of Public Service American Studies Research Institute

Centre for Social Sciences Institute for Political Science

stumpf57@gmail.com

\section{Csaba ERDÖS PhD}

Széchenyi István University, Faculty of Law and Political Sciences

Egyetem tér 1., 9026 Győr, Hungary

University of Public Service, Faculty of Public Governance and International Studies

dr.erdos.csaba@gmail.com 